\title{
ANALISIS KEPUTUSAN DAN METODE PENGHAKIMAN TERHADAP PEMBERIAN WASIAT WAJIBAH KEPADA ANAK TIDAK SAH TARAF DALAM KES NO. 0257/ PDT.G/2012/PA. JBG
}

\begin{abstract}
An Analysis of Decision and Method of Judgment toward Granting Wajibah Will to the Illegitimate Children in the Case Number 0257 / Pdt.G / 2012 / PA. Jbg
\end{abstract}

\author{
Zakiul Fuady Muhammad Daud* \\ Raihanah Hj. Azahari**
}

\begin{abstract}
Children born from illegitimate marriages have a legal impact including inheritance issues. In Islamic perspective, he only inherited from his mother and his mother's family and did not inherit from his biological father. In this case the judge sometimes gives the wajībah will and sometimes not. This study aims to describe the decisions and methods of judgement in the case of illegitimate children
\end{abstract}

* Lecturer of Tarbiyah Department, STAIN Gajah Putih Takengon, Aceh, Indonesia, zakiul_fuady@stain-gpt.ac.id

** Associate Professor, Department Fiqh and Usul, Academy of Islamic Studies, University of Malaya, 50603, Kuala Lumpur, Malaysia, raihan@um.edu.my 
and analyze them in the Shariah perspective. This qualitative study combines empirical studies (law in action) with normative legal studies (law in book) by making judges as respondents. Data collection techniques are carried out through interviews and documentation, while data analysis uses data reduction, data display and conclusion. The results showed that the judge gave the wajibah will to illegitimate children by using the method of extensive interpretation and revoked the grant given to him together with the defendant using the argumentum a contrario method. In the perspective of Shariah, the judge's decision was inappropriate because revoking the grant instead gave wajibah will that is still debatable.

Keywords: decisions, method of judgment, illegitimate children, wajibah will, Shariah

\section{PENDAHULUAN}

Kelahiran seorang anak merupakan anugerah yang diidamidamkan oleh setiap pasangan suami isteri. Namun demikian, jika anak tersebut lahir bukan daripada hasil perkahwinan sah, maka hal ini sangat tidak diharapkan kerana akan memberikan impak terhadap apa-apa hukum yang berkaitan dengan hak pengiktirafan nasab keturunan mahupun kewarisan.

Dalam hal ini Islam memandang bahawa anak yang terlahir daripada perbuatan zina ibu bapanya, maka nasab keturunannya dinasabkan hanya kepada ibunya dan keluarga ibunya sahaja. Sementara dengan bapa biologinya tidak ada apa-apa hubungan nasab. Begitu juga dalam kewarisan, anak yang lahir bukan daripada hasil perkahwinan sah hanya mendapatkan harta pusaka daripada ibunya dan keluarga ibunya sahaja, dan ianya tidak mendapatkan waris daripada bapa biologinya. Hal ini disebabkan dalam hukum kewarisan, Islam sudah menentukan sesiapa yang berhak menerima harta pusaka dan sesiapa yang tidak berhak 
menerimanya. Selain itu, Islam juga sudah menentukan bahagian yang diterima oleh setiap ahli waris. ${ }^{1}$

Namun demikian, dalam amalannya di Mahkamah Agama Indonesia, tidak jarang keputusan hakim yang tidak bersesuaian dengan syarak, ${ }^{2}$ begitu juga dengan kes berhubung dengan anak tak sah taraf, sama ada permohonan pengiktirafan nasab dengan bapa biologinya bagi keperluan pembuatan sijil kelahiran mahupun permohonan mendapatkan harta pusaka. Berkaitan dengan kewarisan anak tak sah taraf dengan bapa biologinya, keputusan yang diberikan hakim berbeza-beza, terkadang kes hakim memberikan harta pusaka berupa wasiat wajibah tetapi pada kes lain hakim tidak memberikannya. Dalam hal ini hakim pada satu masa merujuk kepada fatwa Majelis Ulama Indonesia (seterusnya disingkat dengan MUI) Nombor 11 tahun 2012 tentang kedudukan anak hasil zina dan perlakuan terhadapnya, namun pada masa lain tidak pula merujuk kepada fatwa ini. Perbezaan keputusan hakim adalah disebab ketidakjelasan bahagian anak tidak sah taraf dalam Kompilasi Hukum Islam (yang seterusnya disingkat dengan KHI). kerana dalam peraturan yang mengatur tentang kewarisan hukum Islam di Indonesia yang terangkum dalam KHI tidak menjelaskan tentang bahagian anak tak sah taraf.

Sebagai contoh, perbezaan keputusan tentang anak tak sah taraf adalah sepertimana kes nombor 1595/Pdt.G/2010/PA. Sda. yang mana anak yang lahir tiga hari setelah hari perkahwinan tidak diberikan wasiat wajibah dan nasab anak tersebut juga tidak disandarkan kepada ibunya dan keluarga ibunya. Hal ini disebabkan bapa biologinya tidak mengiktiraf bahawa anak itu anak kandungnya. Sementara keputusan hakim pada kes nombor 0005/Pdt.P/2016/PA. Kdr. memberikan wasiat wajibah kepada anak tak sah taraf.

$1 \quad$ Zakiul Fuady Muhammad Daud \& Raihanah Azahari, "The wajibah will: Alternative wealth transition for individuals who are prevented from attaining their inheritance," International Journal of Ethics and Systems 10.1108/IJOES-09-2018-0133.

2 Zakiul Fuady Muhammad Daud \& Raihanah Azahari, "Amalan penghakiman dalam kes Wasiat wajibah kepada waris berbeza agama: Kajian kes terpilih,” Jurnal Syariah 26, no 2 (2018), 269. 
Oleh itu, satu kajian perlu dibuat untuk mengkaji tentang keputusan hakim dan metode yang digunakan dalam memutuskan perkara yang berkaitan dengan anak tak sah taraf berdasarkan perspektif syarak. Dalam hal ini, pengkaji memilih salah satu kes iaitu kes dengan nombor 0257/Pdt.G/2012/PA. Jbg.

\section{KONSEP ANAK SAH DAN ANAK TAK SAH TARAF BESERTA HUKUMNYA}

Hubungan anak dengan ibu bapa selain dibina melalui hubungan darah tetapi juga dikuatkan dengan adanya pengiktirafan secara syarak. Adanya pengiktirafan daripada syarak ini tidak hanya untuk menghubungkan nama seseorang anak dengan bapa tetapi merupakan dasar bagi hak dan kewajipan yang dipikul oleh masing-masing dalam keluarga. Anak yang sah mengikut Kompilasi Hukum Islam Indonesia (KHI) pada pasal 99 yang menentukan tentang Pemeliharaan Anak menyatakan bahawa anak yang sah menurut undang-undang adalah anak yang lahir daripada perkahwinan yang sah atau hasil persenyawaan dilakukan suami isteri yang sah di luar Rahim (artificial fertilazition) dan dilahirkan oleh isteri tersebut. ${ }^{3}$ Manakala mengikut hukum adat, anak yang sah adalah anak kandung yang lahir daripada perkahwinan ibu bapa yang sah mengikut ajaran agama. ${ }^{4}$

Manakala mengikut para fuqaha, anak sah atau anak syar'i meliputi tiga kategori; iaitu pertama, anak yang lahir daripada hasil perkahwinan yang sah; kedua, anak yang lahir daripada perkahwinan fasid sebelum diketahui kefasidannya, dan ketiganya anak yang lahir daripada hubungan suami isteri yang syubhat. ${ }^{5}$ Oleh yang demikian, anak yang termasuk ke dalam tiga kategori

Undang-Undang RI No. 1 Tahun 1974, 352.

Muhibbin, Moh Muhibbin," Wasiat Wajibah untuk Anak Angkat, Anak di Luar Perkahwinan Yang Sah dan Anak dari Ibu bapa Beda Agama," dalam Problematika Hukum Kewarisan Islam Kontemporer di Indonesia, ed. Muchit A. Karim (Jakarta: Kementrian Agama RI Badan Litbang dan Diklat Puslitbang Kehidupan Keagamaan, 2012), 299. Zakiul Fuady M. Daud, Belajar Praktis Fiqih Mawaris (Takengon, Shakura,2018), 103.

5 Wahbah al-Zuhaylī, al-Fiqh al-Islām̄̄ wa Adillatuhu, vol. 3 (Damshiq, Syria: Dar al-Fikr, 1989), 676. 
ini secara hukum mempunyai hubungan nasab dengan ibu bapanya dan berlaku hak dan kewajipan di antara ibu bapanya dengan anak tersebut termasuk dalam masalah kewarisan. ${ }^{6}$

Walau bagaimanapun, tidak semua perkahwinan sah boleh dijadikan sebagai asas anak sah. Mengikut para fuqaha, anak sah lahir daripada perkahwinan sah minimum setelah enam bulan umur perkahwinan. ${ }^{7}$ Ketentuan ini merupakan kompromi (alJam') daripada dua Surah yang menjelaskan masalah ini, iaitu dalam Surah al-Ahqaf ayat 15 dan Surah Luqman ayat 14 seperti berikut:

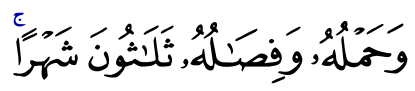

Terjemahan: "Masa mengandung dan menyapihnya selama tiga puluh bulan..."

(Surah Al-Ahqaf, 46: 15)

Manakala surah Luqman ayat 14 sepertimana berikut:

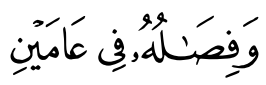

Terjemahan: "Dan menyapihnya selama dua tahun..."

(Surah Luqman, 31: 14)

Ayat pertama menjelaskan tempoh mengandung dan menyusui adalah 30 bulan. Manakala ayat kedua menerangkan tempoh bagi menyusui adalah dua tahun (24 bulan), maka dengan menggunakan metode kompromi, baki tempoh bagi mengandung adalah enam bulan. ${ }^{8}$ Inilah yang dijadikan penanda aras bagi para fuqaha mengenai had minimum masa anak yang dikandung agar disebut sebagai anak sah.

Sebaliknya, anak yang lahir tanpa didahului oleh perkahwinan yang sah, maka dianggap sebagai anak luar nikah. Dalam ketentuan hukum Islam, anak jenis ini disebut sebagai anak zina

$6 \quad$ M. Thahir Maloko, “Anak sah dan anak luar nikah,” Ar-Risalah 10, no. 1 (2010), 45.

7 Abū al-Wālid Muhammad Ibn Aḥmad Ibn Muḥammad Ibn Aḥmad Ibn Rushd, Bidāyah al-Mujtahid wa al-Nihāyah al-Muqtașid, vol. 3 (Bayrūt: Dār al-Ma'rifah, 1978), 352.

8 Wahbah al-Zuhaylī, al-Fiqh al-Islāmī wa Adillatuhu, 675. 
(walad az-zina) disebabkan lahir daripada jalan yang tidak sesuai syarak atau anak hasil daripada hubungan yang diharamkan. ${ }^{9}$ Manakala Hasanayn Muhammad Makluf berpendapat bahawa anak zina merupakan anak akibat hubungan suami isteri yang tidak sah. Apa yang dimaksudkan dengan hubungan yang tidak sah adalah persetubuhan antara dua orang yang tidak diikat oleh ikatan perkahwinan, sama ada atas dasar kedua-duanya suka mahupun disebabkan dirogol, sama ada dilakukan oleh orang yang sudah berkahwin mahupun yang belum berkahwin. ${ }^{10}$ Pandangan ini berbeza dengan yang dipegang oleh undang-undang sivil (BW) yang menyatakan bahawa anak di luar perkahwinan adalah anak yang dibenihkan dan dilahirkan di luar perkahwinan sah. ${ }^{11}$ Sementara mengikut hukum adat, pengertian anak luar nikah digolongkan kepada lima kategori; iaitu: (a) anak daripada hubungan ibu sebelum perkahwinan (b) anak daripada kandungan ibu selepas lama bercerai (c) anak hasil zina dengan orang lain bukan suaminya (d) anak yang tidak diketahui siapa bapanya (e) anak yang lahir tanpa melakukan ikatan perkahwinan sah. ${ }^{12}$

Manakala dalam KHI tidak dijelaskan secara jelas definisi anak di luar perkahwinan sah. Kerana tidak ada penerangan yang jelas, maka makna anak di luar perkahwinan sah merujuk kepada dua makna, iaitu pertama, makna anak yang lahir daripada perkahwinan sah menurut agama tetapi tidak tercatat menurut undang undang dan kedua bermakna anak yang lahir tanpa

\footnotetext{
$9 \quad$ Ibid., 532.
}

10 Hasanayn Muhammad Maklūf, al-Mawārith fì al-Sharī'ah alIslämiyyah (t.t.p.: Maṭba'ah al-Madanī, 1996); Chatib Rasyid, "Menempatkan anak yang lahir di luar nikah secara hukum Islam", Muzakarah Majelis Ulama Indonesia (MUI) (Medan: MUI, 2005), 4.

11 Muhibbin, "Wasiat wajibah untuk anak angkat," 297.

12 Hilman Hadikusuma, Hukum Waris Adat (Bandung: PT. Citra Aditya Bakti, 1999), 68. 
perkahwinan sah (anak zina). ${ }^{13}$ Namun demikian, dalam kajian ini kes yang dipilih adalah kes anak di luar perkahwinan sah dalam kategori pertama.

Definisi di atas berbeza dengan definisi yang diberikan oleh jawatankuasa Kebangsaan Malaysia tahun 2003 yang memberikan batasan jelas tentang anak tidak sah taraf, iaitu:

a) Anak yang dilahirkan di luar nikah sama ada akibat zina atau rogol dan dia bukan daripada persetubuhan syubhat.

b) Anak dilahirkan kurang dari enam bulan dua lahzah (saat) mengikut taqwim qamariah daripada tarikh dan akad."14

Adapun yang menjadi dasar hukum anak luar nikah adalah hadis Rasulullah SAW yang diriwayatkan oleh Bukhari Muslim daripada Aisyah RA sepertimana berikut:

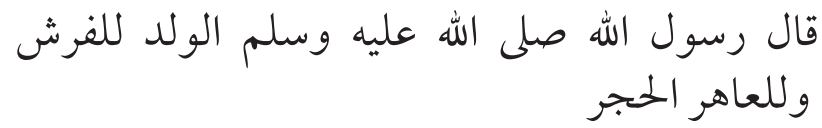

Terjemahan: "Anak untukyang mempunyai katil dan bagi orang yang berzina itu batu...” 15

13 Ketentuan perkahwinan sah di Indonesia diatur pada Undang-Undang Nombor 1 tahun 1974 tentang perkahwinan pasal 2 ayat 1 dan 2 yang memperuntukkan: “(1) Perkahwinan adalah sah apabila dilakukan menurut hukum masing-masing agamanya dan kepercayaannya itu. (2) Tiap-tiap perkahwinan dicatat menurut peraturan undang-undang yang berlaku". Fenomena yang berlaku dalam kalangan masyarakat, terkadang pasangan suami isteri melakukan perkahwinan, secara agama sah, tetapi tidak dilakukan di hadapan jawatan kuasa perkahwinan, sehingga tidak memenuhi undang-undang tersebut di tasa. Maka perkahwinan ini pula dianggap tidak sah secara hukum. Lihat Chatib Rasyid, Anak lahir di luar nikah (secara hukum) berbeza dengan anak hasil zina: Kajian yuridis terhadap putusan MK No. 46 / PUU-VII/2012, tidak diterbitkan, 2012, 6.

14 Paizah Ismail, "Anak tak sah taraf dari perspektif syariah dan perundangan Islam di Malaysia,” Jurnal Fiqh, no. 10 (2013), 83.

15 Al-Șan'ānī, Muhammad Ibn Ismā'īl al-Kahlanī Abū Ibrāhim, 'Izz al-Dīn, Subl al-Salām Sharh Bulūgh al-Maram, vol. 1 (Semarang: Maktabah Toha Putera, t.t.), 210. 
Hadis di atas menerangkan bahawa anak yang sah merupakan anak hasil daripada perkahwinan yang sah, manakala selain itu disebut sebagai anak hasil zina yang pelakunya mesti dihukum rejam dengan batu.

Berkenaan dengan anak luar nikah, ulama empat mazhab (Hanāfiyah, Mālikiyah, Shāfiiyyah dan Ḥanābilah) bersepakat bahawa anak hasil zina hanya memiliki nasab dengan ibunya dan tidak memiliki hubungan dengan bapanya sama ada dalam hukum perkahwinan mahupun hukum kewarisan. Walaupun lelaki yang menabur benihnya mengiktiraf anaknya, namun pengiktirafan ini tidak dianggap kerana anak tersebut merupakan hasil hubungan luar nikah. Walau bagaimanapun, pandangan ini berbeza dengan pendapat Ibn Taimiyah yang tetap mengiktiraf nasab anak zina kepada bapa kandungnya dengan alasan bahawa hukuman zina ditimpakan kepada pelaku zina sama ada di dunia mahupun di akhirat dan tidak diberikan kepada anaknya. ${ }^{16}$ Namun demikian, KHI menjadikan pandangan jumhur ulama sebagai rujukan dalam masalah anak luar nikah sepertimana pada pasal 100 yang menyatakan bahawa anak yang lahir luar nikah hanya mempunyai hubungan nasab dengan ibu atau keluarga ibunya. ${ }^{17}$

Dalam ketentuan fiqh, akibat hukum yang berkaitan dengan hukum kewarisan adalah anak luar nikah tidak dapat saling mewaris dengan bapa kandungnya, meskipun bapanya mengiktirafnya sebagai anaknya. Di sini, anak zina mempunyai kedudukan yang sama dengan anak mula'anah ${ }^{18}$ yang hanya dapat mewaris dengan garis ibunya kerana nasabnya kepada garis ibunya. Berkenaan dengan perkara ini, Wahbah Zuhaylī menyatakan bahawa mengikut ulama Malakiyah, zina merupakan salah satu penghalang daripada penerimaan harta pusaka daripada

\footnotetext{
Ibid., 293.

Undang-Undang RI No. 1 Tahun 1974, 352.

18 Anak mula'anah adalah anak yang lahir daripada ibu yang diingkari oleh suaminya yang dikuatkan dengan sumpah $l i$ 'an, maka nasab dengan bapanya terputus dan segala akibat hukumnya di bawah tanggungjawab ibunya. Sayyid Sābiq, Fiqh al-Sunnah, vol. 3 (Bayrūt: Dār al-Kutub 'Arabī, 1989), 276-277.
} 
bapanya ${ }^{19}$ Pandangan ini merupakan kesepakatan dan $i j m \bar{a}$ ' ulama fiqh mazhab empat serta fiqh Syiah Imamiyah. ${ }^{20}$

Adapun landasan hukumnya adalah hadis Rasulullah SAW yang diriwayatkan oleh 'Alī bin Abī Țālib dari Ibn 'Abbās sepertimana berikut:

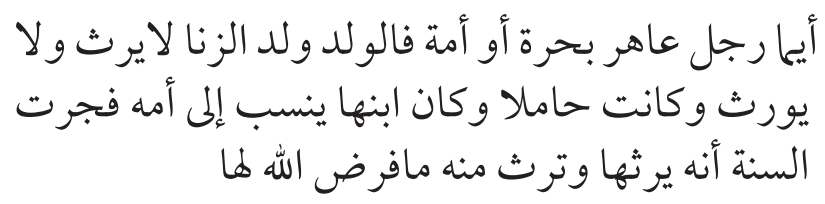

Terjemahan: "Sesiapa lelaki yang berzina sama ada merdeka mahupun hamba sahaya, maka anak tersebut adalah anak zina, tidak mewaris dan tidak diwaris. Dan apabila perempuan tersebut mengandung, anaknya dinasabkan kepada ibunya ..." 21

Manakala dalam ketentuan KHI menyatakan bahawa anak di luar perkahwinan hanya mempunyai hubungan nasab dengan ibunya dan keluarganya sahaja termasuk dalam masalah kewarisan. Ini sepertimana dalam pasal 186 bab III tentang Besarnya Bahagian yang memperuntukkan: "anak yang lahir di luar perkahwinan hanya mempunyai hubungan saling mewaris dengan ibunya dan keluarga dari pihak ibunya", ${ }^{22}$ Dengan demikian, KHI menentukan secara tegas bahawa anak luar nikah hanya dapat mewaris dengan ibunya dan keluarga ibunya sahaja, sepertimana ketentuan dalam hukum Islam.

Walau bagaimanapun, Majelis Ulama Indonesia (MUI) mempunyai pandangan lain berkaitan kedudukan anak luar nikah dengan bapa kandungnya. Melalui fatwa MUI Nombor

19 Wahbah al-Zuhaylī, al-Fiqh al-Islāmī wa Adillatuhu, 383.

20 Ibid., 532.

21 Al-Shawkānī, Mu 66.b Arabyatuhu, rabī, 1989),Nayl al-Aw̄̄, Mu 66.b Arabyatuhu, rabī, 1, vol. 6 (Bayrūt: Dār al-Kutub 'Arabī, 2002), 66.

22 Undang-Undang RI No. 1 Tahun 1974, 379. 
11 tahun 2012 tentang kedudukan anak hasil zina dan perlakuan terhadapnya, maka diputuskan hukum sebagai berikut:23

1) Anak hasil zina tidak mempunyai hubungan nasab, wali nikah, waris, dan nafaqah dengan lelaki yang mengakibatkan kelahirannya.

2) Anak hasil zina hanya mempunyai hubungan nasab, waris dan nafaqah dengan ibunya dan keluarga ibunya.

3) Anak hasil zina tidak menanggung dosa perzinaan yang dilakukan oleh orang yang mengakibatkan kelahirannya.

4) Penzina dikenakan hadd oleh pihak yang berwenang untuk kepentingan menjaga keturunan yang sah.

5) Pemerintah berwenang menjatuhkan hukuman ta 'zir kepada lelaki penzina yang mengakibatkan lahirnya anak dengan mewajibkan untuk:

a) Memenuhi keperluan hidup anak tersebut.

b) Memberi harta setelah ia meninggal melalui wasiat wajibah.

6) Hukuman sebagaimana dimaksud nomor 5 bertujuan melindungan anak, bukan untuk mensahkan hubungan nasab antara anak tersebut dengan lelaki yang mengakibatkan kelahirannya.

Pandangan Majelis Ulama Indonesia ini bertujuan untuk melindungi hak-hak anak zina bukan dengan cara memberikan nasab kepada bapa kandungnya melainkan memberikan hukuman ta $z i r^{24}$ kepada bapa yang mengakibatkan kelahirannya berupa

23 Fatwa Majelis Ulama Indonesia Nombor 11 tahun 2012 tentang Kedudukan Anak Hasil Zina dan Perlakuan Terhadapnya (Jakarta: Komisi Fatwa Majelis Ulama Indonesia), 10.

24 Ta'zir adalah jenis hukuman atas tidak jenayah yang bentuk dan kadarnya bergantung kepada polisi ulul amri (pihak yang memiliki autoriti memberikan hukuman). Ibid., 9. 
kewajipan memenuhi keperluan sara hidup anak dan memberikan harta pusaka melalui wasiat wajibah ketika meninggal dunia.

Wasiat wajibah adalah wasiat yang wajib diberikan oleh hakim kepada ahli waris yang tidak mendapatkan harta waris di mana pelaksanaannya tidak bergantung kepada kehendak yang meninggal tetapi mesti dilaksanakan disebabkan alasan tertentu. ${ }^{25}$ Had maksimum pemberian wasiat wajibah adalah sepertiga daripada harta warisan. Walau bagaimanapun, wasiat wajibah ini masih dipertentangkan dan memerlukan ijtihad para ulama. ${ }^{26}$ Dalam hal ini, jumhur menyatakan hukum wasiat wajibah kepada ahli waris yang tidak mendapatkan pusaka adalah sunah, manakala Ibn Hazm menyatakan sebaliknya. ${ }^{27}$

Adanya hukuman ta'zir berupa wasiat wajibah bertujuan; pertama, untuk memberikan keadilan dan perlindungan hukum kepada anak zina agar tidak didiskriminasikan. Kedua, memberikan tanggungjawab kepada bapa kandungnya atas perbuatannya yang mengakibatkan anaknya lahir sebagai anak zina dan ketiga sebagai bentuk kesan pencegahan agar orang lain tidak melakukan perbuatan zina.

Pemberian wasiat wajibah kepada anak luar nikah yang difatwakan MUI merupakan bentuk hukuman ta'zir kepada bapa kandungnya. Oleh yang demikian, realiti yang berlaku di Mahkamah Agama, terdapat keputusan penghakiman yang tidak komitmen dan konsisten dengan ketentuan yang ada dalam

25 Suparman Usman \& Yusuf Somawinata, Fiqh Mawaris: Hukum kewarisan Islam (Jakarta: Gaya Media, 1997), 163.

26 Daud \& Azahari, "Amalan Penghakiman dalam Kes Wasiat Wajibah," 271.

27 Ibn Hazm al-Andalūsī, al-Muhallā bi al-Athar, vol. 9 (Bayrūt: Dār al-Kutub al-'Ilmiyyah, 2003), 313-314. 
KHI, sesetengah hakim mengikut ketentuan dalam KHI, namun sesetengah hakim yang lain mengikuti fatwa MUI. ${ }^{28}$

\section{METODOLOGI KAJIAN}

Kajian kualitatif ini merupakan kajian gabungan antara kajian empiris (law in action) dan kajian undang-undang (law in book) terhadap keputusan hakim yang berkaitan dengan kes pemberian wasiat wajibah terhadap anak tak sah taraf yang berlaku di pengadilan agama di Jawa Timur Indonesia.

Dalam menentukan sumber data, penulis menggunakan kaedah persampelan bertujuan (purposive sampling); iaitu memilih sumber data tertentu dengan pertimbangan tertentu. ${ }^{29}$ Dalam hal ini penulis memilih seramai tiga orang hakim yang terdiri daripada seorang Hakim Agung, dan dua orang Hakim tahap I daripada Mahkamah Agama atau Mahkamah Rendah di salah satu daerah di wilayah Jawa Timur, Indonesia.

Adapun kaedah pengumpulan data dalam kajian ini adalah temu bual dan dokumentasi. Temu bual (interview) yang dijalankan adalah perjumpaan bersama responden untuk bertukar maklumat melalui soalan-soalan yang dikemukakan sehingga dapat dibina makna yang berkenaan dengan topik tertentu. Bentuk kaedah temu bual ini dalam kajian ini adalah separa berstruktur (semi structure interview), di mana penulis berhasrat untuk mendapatkan maklumat yang lebih mendalam dan terbuka. Di sini, penulis mengemukakan beberapa soalan berkaitan topik kajian dan dalam masa yang sama, penulis juga memberikan soalan tambahan semasa proses temu bual dijalankan sekiranya diperlukan.

28 Sepertimana Perundangan Mahkamah Agung RI no. 179/K/SIP/1960 bertarikh 23 Oktober 1961 menyatakan bahawa berdasarkan sifat kemanusiaan dan keadilan umum, atas hakikat persamaan hak antara anak sah dan anak di luar perkahwinan sah, maka anak-anak di luar perkahwinan dan anak-anak sah daripada peninggal harta bersamasama berhak atas harta pusaka. Dengan perkataan lain dianggap sebagai anak sah. Muhibbin, "Wasiat wajibah untuk anak angkat," 305.

29 Chua Yan Piaw, Kaedah dan Statistik Pengkajian: Asas Statistik Pengkajian Buku 2 (Malaysia: McGraw-Hill, 2006), 301. 
Manakala dokumentasi adalah kaedah pengumpulan data di mana dokumen sebagai data. Dokumen dapat berupa catatan kejadian lepas, sama ada dalam bentuk tulisan, gambar mahupun karya-karya seseorang. ${ }^{30}$ Dalam kajian ini, dokumen yang dikumpulkan adalah berupa perundangan, iaitu hasil keputusan mahkamah yang berkaitan dengan wasiat wajibah kepada anak tak sah taraf.

Seterusnya penulis menganalisis data kualitatif deskriptif dengan menggunakan pendekatan yang telah dikemukakan oleh Miles dan Huberman dalam Sugiyono ${ }^{31}$ yang menyatakan bahawa analisis data dalam kajian kualitatif dilakukan secara berterusan dan interaktif sehingga selesai, meliputi data collection (pengumpulan data), data display (penyajian data), data reduction (reduksi data) dan conclusion (penarikan kesimpulan).

\section{KEPUTUSAN DAN METODE PENGHAKIMAN TERHADAP PEMBERIAN WASIAT WAJIBAH KEPADA ANAK TIDAK SAH TARAF}

\section{Permasalahan}

Dalam kes ini, yang meninggal dunia adalah seorang lelaki yang bernama Soehardjo. Soehardjo memiliki enam orang saudara yang semuanya sudah meninggal dunia; iaitu Sarminah, Sumarlik, Karyoto, Kusnadi dan Siswoyo. Selain itu, terdapat dua lelaki iaitu Ismunandar dan Setyo Wibowo di mana kedua-duanya mengiktiraf bahawa mereka adalah anak kandung daripada Allahyarham Soehardjo. Ismunandar berkeyakinan bahawa beliau adalah anak tunggal hasil perkahwinan antara Soehardjo dengan Musriah. Sementara Setyo Wibowo pula mengiktiraf bahawa beliau juga anak daripada hasil perkahwinan antara Soehardjo dengan Masrikah alias Katoyah. Kedua-duanya tinggal bersama Soehardjo, namun dalam pandangan Ismunandar, Setyo Wibowo adalah anak angkat bapanya yang pada hakikatnya ia adalah anak

30 Chua Yan Piaw, Kaedah dan Statistik Pengkajian: Asas Statistik Pengkajian Buku 2, 326.

31 Chua Yan Piaw, Kaedah dan Statistik Pengkajian: Asas Statistik Pengkajian Buku 2, 334. 
daripada saudara bapanya yang bernama Siswoyo. Ismunandar berkahwin tiga kali; perkahwinan pertama dengan Munawaroh dan mempunyai dua orang anak iaitu Wahyu Ismawarti dan Didik, kemudian bercerai. Seterusnya Ismunandar berkahwin dengan Umaroh dan mempunyai dua orang anak iaitu Titik Kusnawati dan Wiji Utami, kemudian bercerai. Ketiga berkahwin dengan Sulikah dan mempunyai dua orang anak juga iaitu Feby Fedia Susanto dan Anita.

Ketika Soehardjo sedang sakit sebelum meninggal, pada 8 Ogos 1990 ianya telah menghibahkan sejumlah harta kepada saudaranya Siswoyo juga Setyo Wibowo serta cucunya Wahyu Ismawarti dan Didik. Dalam kes ini, yang menjadi pihak plaintif adalah Ismunandar, sedangkan yang defendan adalah Setyo Wibowo. Selain itu Wahyu Ismawarti dan didik yang keduaduanya adalah anak Ismunandar menjadi turut defendan I dan II. Adapun harta peninggalan Soehardjo adalah:

a) Tanah pekarangan seluas $670 \mathrm{~m}^{2}$ yang di atasnya berdiri bangunan rumah seluas $10 \mathrm{~m} \times 4 \mathrm{~m}$ dan sebahagiannya dihibahkan kepada turut defendan I tetapi dikuasai oleh defendan.

b) Tanah pekarangan seluas $820 \mathrm{~m}^{2}$ yang di atas berdiri bangunan rumah $12 \mathrm{~m}$ x $6 \mathrm{~m}$ yang sebahagiannya seluas $420 \mathrm{~m}^{2}$ dihibahkan kepada Allahyarham Siswoyo sehingga dikuasai oleh defendan.

c) Tanah sawah seluas $4.470 \mathrm{~m}^{2}$ yang sebahagian seluas 1.670 $\mathrm{m}^{2}$ dijual kepada Kotiyah, sebahagiannya lagi seluas $1.400 \mathrm{~m}^{2}$ dikuasai oleh defendan dan bakinya dihibahkan kepada turut defendan II.

d) Tanah sawah seluas $6.080 \mathrm{~m}^{2}$ yang sebahagiannya seluas 5.970 $\mathrm{m}^{2}$ dihibahkan kepada turut defendan I tetapi dikuasai oleh defendan.

e) Tanah seluas $780 \mathrm{~m}^{2}$ yang di atasnya berdiri bangunan rumah dan tanah seluas $1.400 \mathrm{~m}^{2}$ yang dihibahkan kepada turut defendan II tetapi dikuasai oleh plaintif. 
Dalam kes ini terdapat beberapa tuntutan yang disampaikan oleh plaintif kepada pihak defendan, iaitu:

a) Plaintif (Ismunandar) adalah anak tunggal Soehardjo, manakala defendan (Setyo Wibowo) adalah anak Siswoyo yang merupakan saudara Soehardjo.

b) Plaintif adalah anak lelaki seorang diri daripada Soehardjo, oleh sebab itu plaintif berperanan sebagai ahli waris tunggal Soehardjo. Manakala defendan dan turut defendan I dan II sebagai ahli waris yang terhalang oleh plaintif.

c) Bahawa Soehardjo ketika meninggal dunia telah meninggalkan harta pusaka berupa tanah pekarangan, beberapa rumah dan tanah sawah (ladang), tetapi tanah pekarangan dan tanah sawah tersebut telah dihebahkan kepada defendan, turut defendan I dan II tanpa ada baki sedikitpun yang diberikan kepada plaintif sebagai ahli warisnya.

d) Bahawa akibat hibah tersebut, plaintif kehilangan haknya untuk mewarisi harta peninggalan tersebut.

Kedua-dua plaintif dan defendan mengemukakan dua orang saksi bagi menguatkan keterangan masing-masing pihak yang bertikai. Berdasarkan kepada penjelasan daripada kedua-dua saksi yang dikemukakan oleh plaintif bahawa Ismunandar adalah anak daripada Soehardjo dan ianya merupakan anak tunggal. Manakala defendan merupakan saudara sepupu plaintif yang mana bapa kandung defendan adalah saudara kandung bapa plaintif. Selain daripada itu, plaintif juga membawa bukti surat nikah ibu bapanya yang dikeluarkan oleh Pejabat Kenaiban Kecamatan Gudo Daerah Jombang dengan Nombor 238 bertarikh 16 April 1940 dan buktibukti lain yang menyokong keterangan plaintif.

Manakala daripada pihak defendan pula mengemukakan dua orang saksi. Saksi pertama menyatakan bahawa Soehardjo mempunyai dua orang anak lelaki iaitu Ismunandar (plaintif) dan Setyo Wibowo (defendan). Manakala Siswoyo dengan Ismunandar tidak mempunyai hubungan kekeluargaan apapun. Sedangkan keterangan saksi kedua menyatakan bahawa Soehardjo berkahwin dengan Katoyah dan mempunyai anak yang bernama Setyo Wibowo. Sedangkan Siswoyo adalah saudara Soehardjo dan 
ianya mempunyai dua orang anak; iaitu Utoro dan Yayuk. Selain daripada itu, pihak defendan juga membawa beberapa alat bukti salah satunya adalah Surat Nikah yang dikeluarkan oleh Pejabat Kenaiban Kecamatan Gudo Daerah Jombang dengan Nombor 238 bertarikh 16 April 1940 dan bukti-bukti lain yang menyokong keterangan defendan.

Selain menerima keterangan daripada para saksi yang dikemukakan oleh pihak plaintif dan defendan, selama proses perbicaraan, Majlis juga mengemukakan saksi lain yang berkediaman di sebelah salah satu rumah yang menjadi objek pertikaian dan menyatakan bahawa Setyo Wibowo adalah anak kandung daripada Siswoyo, saudara Soehardjo, yang mana ianya dipelihara oleh Soehardjo sejak kecil.

Selepas mendengarkan keterangan daripada defendan berserta saksi yang dikemukakan oleh defendan, untuk menguatkan lagi dalil yang dinyatakan oleh plaintif, plaintif memohon diberi kebenaran untuk melafazkan sumpah di hadapan Pengadilan Agama (Mahkamah Agama) bahawa Ismunandar (plaintif) adalah anak Soehardjo. ${ }^{32}$ Di sini dapat diketahui bahawa Setyo Wibowo (defendan) merupakan anak Seohardjo yang berkahwin secara sirri dengan perempuan lain yang bernama Katoyah. Dengan kata lain, defendan adalah anak tidak sah taraf Soehardjo.

\section{Keputusan Penghakiman}

Berdasarkan kepada keterangan yang diberikan oleh plaintif dan defendan ditambah pula keterangan daripada para saksi serta bukti-bukti yang tepat, maka Majlis hakim memutuskan bahawa:

a) Dalil-dalil tuntutan plaintif yang menyatakan bahawa ianya (plaintif) adalah anak tunggal daripada Soehardjo terbukti.

b) Harta peninggalan Soehardjo yang telah dihebahkan kepada defendan, turut defendan I dan II tidak memiliki undangundang yang sah dan menjadi harta allahyarham Soehardjo

32 Isi sumpah plaintif adalah: "Demi Allah bahawa saya (Ismunandar) adalah anak tunggal Soehardjo dan tidak ada anak lain selain saya (Ismunandar), saya bersumpah apabila saya berbohong saya bersedia menerima adzab dari Allah SWT." 
yang belum dibahagikan.

c) Plaintif sebagai ahli waris tunggal Soehardjo terhadap seluruh harta peninggalannya setelah dikurangi $1 / 3$ bahagian untuk diberikan kepada defendan, turut defendan I dan II yang berperanan sebagai anak angkat.

\section{Landasan Hukum}

Yang menjadi landasan hukum yang digunakan hakim dalam memberikan keputusan adalah:

a) Berkaitan status nasab antara plaintif dengan defendan dengan Soehardjo, masing-masing pihak telah mengemukakan bukti tulisan (surat nikah) dan dua orang saksi yang memberi keterangan di bawah sumpah bahawa dua orang saksi plaintif menguatkan dalil-dalil plaintif, begitu pula dua orang saksi defendan juga menguatkan dalil-dalil defendan. Manakala bukti-bukti yang diajukan kedua pihak, sama ada plaintif mahupun defendan telah memenuhi batasan minimum nilai pembuktian. Oleh yang demikian, kedua-dua pihak memiliki kekuatan bukti yang seimbang. Namun demikian, plaintif telah melengkapi pembuktiannya dengan melafazkan sumpah, dengan demikian kekuatan bukti yang dimiliki plaintif lebih tinggi daripada defendan.

b) Dalam kes ini, plaintif adalah ahli waris tunggal Soehardjo, manakala defendan, turut defendan I dan II yang dipelihara dan dibesarkan oleh Soehardjo sejak kecil yang mengikut adat Jawa dianggap sebagai anak angkat Soehardjo. Oleh yang demikian, berdasarkan kepada pasal $210 \mathrm{KHI}$ ayat 1 yang memperuntukkan: "Orang yang telah berumur sekurangkurangnya 21 tahun, berakal sehat dan tanpa adanya paksaan dapat menghibahkan sebanyak-banyaknya $1 / 3$ harta bendanya kepada orang lain atau institusi di hadapan dua orang saksi untuk dimiliki", maka hibah yang dilakukan oleh Soehardjo kepada defendan, turut defendan I dan II mempunyai cacat hukum. Oleh yang demikian, akta hibah yang diajukan oleh defendan harus dinyatakan tidak mempunyai undang-undang yang sah. Begitu pula dengan sijil tanah tidak menjadi jaminan 
kejelasan hukum bagi pemiliknya, ini berdasarkan kepada UU No. 5/1960 tentang agraria menggunakan sistem publikasi negatif yang bermakna sijil bukanlah bukti yang memiliki kekuatan pembuktian yang mutlak dan sijil tanah memiliki kekuatan pembuktian yang kuat selama tidak dapat dibuktikan oleh bukti lain. Ini juga sesuai dengan pasal 19 ayat 2 huruf c UUPA yang menyatakan bahawa sijil tanah yang dikeluarkan dapat menjadi alat bukti yang kuat. Walau bagaimanapun, ketetapan ini bukan suatu jaminan disebabkan sistem publikasi negatif yang memberikan kesempatan orang lain untuk membatalkan kesahan sijil tersebut. Selain itu, landasan yang diguna pakai hakim adalah perundangan keputusan MA No. 459/R/Sip/1975 bertarikh 8 September 1975 yang menyatakan bahawa dengan memperhatikan kepada stel sel negatif tentang pendaftaran tanah yang berlaku di Indonesia, maka terdaftarnya nama seseorang di dalam register bukanlah menjadi pemilik tanah tersebut apabila kesahannya dapat dibuktikan oleh pihak lain.

c) Pasal 209 ayat 2 KHI yang menyatakan bahawa anak angkat yang tidak menerima wasiat diberi wasiat wajibah sebanyakbanyaknya $1 / 3$ daripada harta ibu bapa angkatnya.

\section{Metode Penghakiman}

Menurut Hakim Agung Amran Suadi dan Hakim Muhajir, hakim dalam menyelesaikan kes ini dengan menggunakan metode tafsiran sistematik. ${ }^{33}$ Hakim menggunakan metode ini untuk mencari jalan pertengahan antara perakuan antara plaintif dan defendan yang kedua-duanya memiliki undang-undang yang sah dan serupa terhadap kedudukan mereka sebagai anak yang sah daripada pewaris dengan pembuktian surat nikah, saksi-saksi dan sebagainya. Namun plaintif memohon untuk bersumpah bahawa ianya merupakan ahli waris tunggal dari pewaris, hakimpun

33 Tafsiran sistematik adalah dengan menggabungkan pentafsiran undang-undang dengan undang-undang yang lain, bahkan menghubungkannya dengan keseluruhan sistem hukum yang ada. Fauzan, Kaidah Penemuan Hukum Yurisprudensi Bidang Hukum Perdata (Jakarta: Kencana, 2014), 55. 
menerima permohonan plaintif untuk bersumpah sehingga hakim lebih menguatkan bukti yang dimiliki plaintif. Perkara ini diatur dalam KHI dan undang-undang sehingga hakim menggabungkan kedua-dua hukum tersebut. ${ }^{34}$

Selain daripada itu, menurut pendapat kedua hakim di atas, majlis hakim dalam kes ini menggunakan metode argumentum a contario $^{35}$ terhadap pasal $210 \mathrm{KHI}$ yang memperuntukkan: "orang yang telah berumur sekurang kurangnya 21 tahun, berakal sehat dan tanpa paksaan dapat menghibahkan sebanyak banyak $1 / 3$ harta bendanya kepada orang lain atau institusi di hadapan dua orang saksi untuk dimiliki". Hakim memutuskan sesuatu yang berbeza dengan apa yang termaktub di dalam pasal tersebut sehingga berlaku hukum sebaliknya. Dengan kata lain, hibah yang diberikan oleh pewaris kepada defendan dan turut defendan I dan II tidak sah menurut undang-undang. ${ }^{36}$

Tambahan pula, menurut Hakim Agung Amran Suadi menyatakan bahawa majlis hakim juga menggunakan metode tafsiran ekstensif. ${ }^{37}$ Hakim menafsirkan undang-undang yang melebihi batasan-batasan kebahasaan terhadap KHI pasal 209 ayat 2 yang berkaitan dengan anak angkat yang tidak menerima wasiat diberi wasiat wajibah sebanyak-banyaknya $1 / 3$ daripada harta ibu bapa angkatnya. Namun pada kenyataannya hakim memberikan

34 Dr. Drs. Amran Suadi, SH, M.Hum, M.M.(Hakim Agung Mahkamah Agung R.I), dalam temu bual bersama penulis pada 7 Mac 2017; Drs. Muhajir, SH, M. Hum (Hakim Agama Mahkamah Agama, Bojonegoro), dalam temu bual bersama penulis pada 25 Januari 2017.

35 Argumentum a contrario adalah menerangkan makna undangundang berdasarkan pengertian yang sebaliknya daripada peristiwa konkrit yang dihadapi dengan peristiwa yang diatur dalam undangundang. Adakalanya suatu peristiwa tidak secara khusus diatur dalam undang-undang, tetapi kebalikan dari peristiwa tersebut diatur oleh undang-undang. Sudikno Mertokusumo dan A. Plito, Bab-Bab tentang Penemuan Hukum, Cet.2 (Bandung: Citra Aditya Bakti, 2013), 26.

36 Ibid.

37 Tafsiran ekstensif ialah pentafsiran terhadap undang-undang yang melebihi batasan-batasan tafsiran kebahasaan. Sudikno Mertokusumo dan A. Plito, Bab-Bab tentang Penemuan Hukum, 20. 
wasiat wajibah kepada defendan, turut defendan I dan II padahal mereka bukanlah anak angkat dari pewaris, malahan defendan adalah anak yang dipertikaikan kesahan nasabnya ke pewaris dan turut defendan I dan II merupakan cucu kandung dari pewaris atau anak dari plaintif. ${ }^{38}$

Manakala Hakim Zamroni menambahkan bahawa majils hakim dalam kes ini juga menggunakan metode tafsiran sistematik. Melalui metode ini, hakim membandingkan aturan yang termaktub dalam KHI dengan Undang-Undang No. 5 tahun 1960 tentang agraria dalam rangka menolak sijil yang dimiliki oleh defendan bukanlah bukti yang kuat disebabkan sistem publikasi negatif yang memberikan kesempatan orang lain untuk membatalkan kesahan sijil tersebut. ${ }^{39}$

\section{ANALISIS KEPUTUSAN DAN METODE PENGHAKIMAN TERHADAP PEMBERIAN WASIAT WAJIBAH KEPADA ANAK TIDAK SAH TARAF}

\section{Analisis Keputusan Hakim}

Dalam menanggapi kes ini, pengkaji huraikan secara umum keputusan yang dikeluarkan oleh hakim bagi mendapatkan kefahaman yang menyeluruh. Kronologi kes ini adalah terdapat dua orang (plaintif dan defendan) yang kedua-duanya mengaku bahawa mereka adalah anak daripada Soehardjo. Kedua-dua orang ini telah membawa bukti yang kuat dan dapat dipercaya secara hukum, namun demikian plaintif berani bersumpah bahawa ianya adalah anak tunggal daripada Soehardjo. Disebabkan kedua-dua plaintif dan defendan mempunyai bukti yang sama kuat, tetapi plaintif menambahi dengan sumpah, maka hakim memutuskan bahawa plaintif adalah anak tunggal daripada Soehardjo. Dari sini, secara tersirat, nampak bahawa plaintif merupakan anak daripada hasil perkahwinan sah antara Soehardjo dengan Masrikah, manakala defendan adalah anak daripada hasil perkahwinan yang

38 Dr. Drs. Amran Suadi, SH, M.Hum, M.M.(Hakim Agung Mahkamah Agung R.I), dalam temu bual bersama penulis pada 7 Mac 2017.

39 Drs. Zamroni, SH. M. Hum. (Hakim Agama Mahkamah Agama Sumenep) dalam temu bual bersama penulis pada 23 Januari 2017. 
tidak sah menurut undang-undang. Oleh yang demikian, kes ini masuk dalam kategori anak tidak sah taraf.

Berkaitan dengan keputusan pertama, menurut perspektif syarak, dapat pengkaji rangkumkan bahawa terdapat lima cara pembuktian perakuan anak iaitu dengan al-firasy, perakuan, kesaksian, al-qiyafah dan al-qur'ah. Menurut ulama, yang dimaksudkan dengan al-Firasy ${ }^{40}$ adalah nasab anak yang dinasabkan kepada suami atau isteri yang melakukan perkahwinan sah. Bagi bapa, perakuan anak sah apabila diikat oleh ikatan sah, manakala bagi ibu pula, perakuan anak sah apabila anak tersebut berada dalam kandungan ibunya. Perakuan jenis ini berdasarkan kepada hadis Rasulullah yang maksudnya: "Anak itu adalah milik pemilik perkahwinan yang sah, sementara bagi yang berzina adalah batu" (H.R. Bukhari dan Muslim). Sedangkan perakuan adalah pengiktirafan seseorang terhadap anaknya ataupun ibu bapanya. ${ }^{41}$

Manakala yang dimaksudkan dengan kesaksian adalah metode pembuktian nasab anak dengan cara mengemukakan dua orang saksi yang bersaksi bahawa fulan adalah anak fulan dan fulanah, jika kedua-dua orang saksi tersebut mengiktiraf bahawa fulan sememangnya anak fulan dan fulanah, maka kesaksian ini dapat diterima dan sah dalam pandangan Islam. ${ }^{42}$ Seterusnya

$40 \quad$ Khalifah 'Alī Al-Ka'bi, Al-Bashmah Al-Wiratsiyah (Yordania: Dār Al-Nafâ'is, 2006), 172.

41 Bagi cara pembuktian dengan perakuan, perlu memenuhi lima syarat, iaitu: (1) anak yang diiktiraf tidak diketahui nasabnya (2) anak tersebut tidak mempunyai nasab dengan orang lain (3) perakuannya logik (misalnya ada kemiripan) (4) perakuan ini bagi anak kecil, bagi anak yang baligh syaratnya ianya tidak mengelak (5) yang mengiktiraf sebagai bapa adalah baligh dan berakal. Lihat Bandar bin Fahd as-Suwailim, al-Bashmah al-Waratsiyah wa Atsaruha fin Nasab (Yordania: Dār al-Nafâ'is, 2006), 98.

$42 \quad$ Ibid., 99. 
yang dimaksudkan dengan al-qiyafa $h^{43}$ adalah metode dalam menentukan hubungan nasab dengan melihat kemiripan bagi dua orang yang tidak diperoleh melalui qarinah (bukti) lain, ini disebabkan kemungkinan terdapat keserupaan antara anak dengan bapanya. Jika zaman dahulu qiyafah dilakukan dengan menggunakan deria manusia sahaja, maka pengembangan daripada qiyafah pada zaman sekarang adalah dengan menggunakan tes DNA di mana tahap kebolehpercayaannya mendekati $100 \%$. Walau bagaimanapun, mengikut $i j m \bar{a}^{\prime}$ ulama kontemporer, ujian DNA merupakan metode paling akhir yang dapat dilakukan oleh seseorang bagi mengenali nasab seseorang anak selepas metode lain sudah dilalui. ${ }^{44}$ Metode terakhir adalah al-qur'ah (undian) iaitu metode paling akhir selepas metode lain bagi anak yang tidak diketahui siapa nasabnya. Golongan yang bersetuju dengan metode ini hanyalah golongan Zhahiriyah yang berlandaskan kepada hadis yang diriwayatkan oleh Zayd bin Arqam. ${ }^{45}$

43 Metode ini biasa diamalkan oleh masyarakat Arab pada masa Jahiliyah dan Rasulullah SAW pula menggunakan metode ini untuk menentukan bahawa Usamah bin Zayd adalah anak daripada Zayd bin Haritsah. Metode ini hanya dapat dilakukan bagi kalangan tertentu yang mempunyai kepakaran dalam mengenali keserupaan fizik pada manusia seperti warna kulit, bentuk mata, bentuk kaki dan sebagainya. Adapun syarat yang perlu dimiliki oleh qaif adalah Islam, adil, berpengalaman, lelaki yang merdeka, bilangannya lebih daripada seorang. Lihat Ibn Taymiyyah, Abū al-'Abbās Taqī al-Dīn Aḥmad Ibn 'Abd al-Halīm, Majmū' al-Fatawā li Ibn Taymiyyah, vol. 20 (t.t.p.: al-Maktabah at-Tawfiqqiyah, t.t.), 351.

44 Rabithah al-'Alam al-Islami, Fatwa al-Majma' al-Fiqhi al-Islami pada muktamar ke-16 (Mekkah, 2002).

45 Dari Zayd bin Arqam, suatu ketika 'Alī di Yaman, didatangkan seorang perempuan yang disetubuhi tiga lelaki pada satu masa suci. 'Alī bertanya kepada dua lelaki: "adakah kalian mengiktiraf bahawa anak ini adalah anak kalian?” kedua-duanya tidak mengiktiraf, dan soalan ini diulang tiga kali, namun kedua-duanya memberikan jawapan yang sama. Akhirnya 'Alī menyuruh untuk qur'ah, nama siapa yang keluar, maka itu yang menjadi bapa anak tersebut dan didenda sebanyak $2 / 3$ diyat. Ketika peristiwa ini disampaikan kepada Rasulullah SAW, Rasulullah SAW tertawa sehingga gigi gerahamnya nampak. Ibn Hazm al-Andalūsī, al-Muhallā bi al-Athar, vol. 9, 341. 
Berkaitan dengan kes ini, apabila dianalisis cara hakim memutuskan perakuan anak, maka jelas bahawa hakim menggunakan jenis pembuktian nasab dengan al-firasy (bukti berupa buku nikah ibu bapa dan akta kelahiran), kesaksian (mengemukakan dua orang saksi) dan perakuan (sumpah). Di sini, rupanya plaintif menggunakan ketiga-tiga jenis pembuktian, manakala defendan hanya menggunakan dua jenis pembuktian (al-firasy dan kesaksian), maka bukti yang lebih banyak yang digunapakai. Oleh yang demikian, dalam pandangan pengkaji, metode yang dilakukan oleh hakim sudah bersesuaian dengan syarak.

Seterusnya, dalam kes ini pula hakim memutuskan mencabut semula hibah yang diberikan kepada defendan dan turut defendan I dan II dan hakim memberikan bahagian daripada harta peninggalan Soehardjo sebanyak 1/3 dengan jalan wasiat wajibah, sementara baki harta tersebut menjadi hak ahli warisnya iaitu plaintif. Dalam kes ini, timbul persoalan mengenai penarikan semula hibah yang telah diberikan oleh allahyarham Soehardjo kepada defendan, turut defendan I dan II yang dicabut semula. Padahal dalam tinjauan syarak, hibah boleh diberikan kepada sesiapa yang dikehendaki oleh pemberi hibah dan penarikan semula hibah yang dibenarkan adalah yang dilakukan bapa kepada anak kandungnya, selain itu tidak dibenarkan. Ini berdasarkan sabda Rasulullah SAW sepertimana berikut:

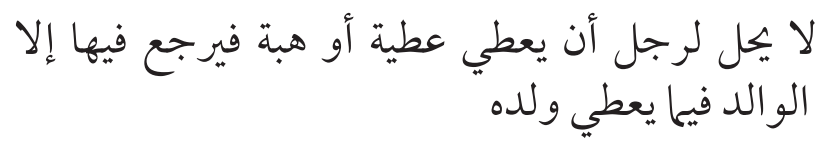

Terjemahan: Tidak halal bagi seorang Muslim memberikan suatu pemberian atau memberikan hibah kemudian mengambilnya kembali, kecuali pemberian seorang ayah kepada anaknya. ${ }^{46}$

46 Diriwayatkan oleh Abū Dāwud dalam kitab “ al Buyu” bab "ar Ruju' fil Hibah" no. 3539. At Tirmizi dalam kitabnya “ al Buyu” bab “maa ja'a fir ruju' fil hibah", no. 1299. An Nasai dalam kitabnya "al Hibah", bab “ ruju'ul walid fima yu'thi waladahu” no. 3690. 
Bahkan yang dilakukan hakim adalah mencabut semula hibah yang diberikan kepada defendan, turut defendan I dan II, kemudian menggantinya dengan memberikan wasiat wajibah sebanyak $1 / 3$ bagi ketiga-tiga orang tersebut. Di sini, pengkaji melihat bahawa hakim membatalkan sesuatu yang sememangnya dibenarkan dalam syarak (menarik hibah) malahan melakukan sesuatu yang hukumnya masih diperdebatkan (pemberian wasiat wajibah). Oleh yang demikian, dalam pandangan pengkaji keputusan membatalkan hibah kepada para defendan dan menggantinya dengan memberikan wasiat wajibah tidak bersesuaian dengan syarak. Hal ini selari dengan kajian yang dijalankan oleh Daud dan Azahari yang mana hakim mencabut kembali hibah yang diberikan kepada anak angkat dengan menganalogikan kepada anak kandung. ${ }^{47}$

Keputusan ini selari dengan keputusan hakim pada kes nombor 0005/Pdt.P/2016/PA. Kdr. yang memberikan wasiat wajibah kepada anak tak sah taraf tetapi anak tersebut tidak mempunyai hubungan nasab dengan bapa biologinya. Keputusan kes dalam kajian ini berbeza dengan keputusan hakim pada kes nombor 1595/ Pdt.G/2010/PA. Sda. dimana hakim tidak memberikan wasiat wajibah kepada anak tak sah taraf. Perbezaan pemberian wasiat wajibah ini menunjukkan bahawa hakim dalam memutuskan perkara dengan melihat kronologi kesnya sehingga menyebabkan terjadinya perbezaan antara memberikan wasiat wajibah mahupun tidak.

Paling akhir keputusan tentang pemberian baki harta pusaka kepada plaintif sebagai ahli waris tunggal adalah sesuai dengan syarak. Menurut perspektif syarak, plaintif menerima baki harta pusaka selepas dikurangkan 1/3 yang berperanan sebagai 'așabah bi al-nafs kerana beliau merupakan anak lelaki kandung allahyarham Soehardjo.

\section{Analisis Metode Penghakiman}

Metode pengeluaran hukum yang digunakan dalam kes ini

47 Zakiul Fuady Muhammad Daud \& Raihanah Azahari, "Wasiat wajibah kepada anak angkat: Analisis terhadap keputusan dan metode penghakiman dalam kes No 459/Pdt.G/2013/PTA Sby," Jurnal Fiqh, no 15 (2018), 57. 
sebagaimana disampaikan oleh Hakim Agung Amran Suadi dan Hakim Muhajir menggunakan metode pengeluaran hukum tafsiran sistematik. Iaitu ketika hakim mencari jalan pertengahan perakuan antara plaintif dan defendan yang kedua-duanya memiliki undangundang yang sah dan serupa terhadap kedudukan mereka sebagai anak yang sah daripada pewaris dengan pembuktian surat nikah, saksi-saksi dan sebagainya. Namun plaintif memohon untuk bersumpah bahawa ianya merupakan ahli waris tunggal daripada pewaris, hakim menerima permohonan plaintif untuk bersumpah sehingga hakim lebih menguatkan bukti yang dimiliki plaintif. ${ }^{48}$

Pengkaji memandang penggunaan metode tersebut merupakan suatu keharusan. Kerana menurut perspektif syarak diatur cara pembuktian anak iaitu dengan al-firasy, perakuan, kesaksian, al-qiyafah dan al-qur'ah. Dalam kes ini, hakim memenangkan plaintif yang telah memberikan tiga jenis pembuktian, iaitu alfirasy dengan mengemukakan bukti-bukti yang menyokong, kesaksian dengan menghadirkan dua orang saksi dan perakuan dengan bersumpah bahawa ianya adalah anak tunggal daripada Soehardjo. Hal tersebut juga selari dengan sabda Rasulullah SAW sepertimana berikut:

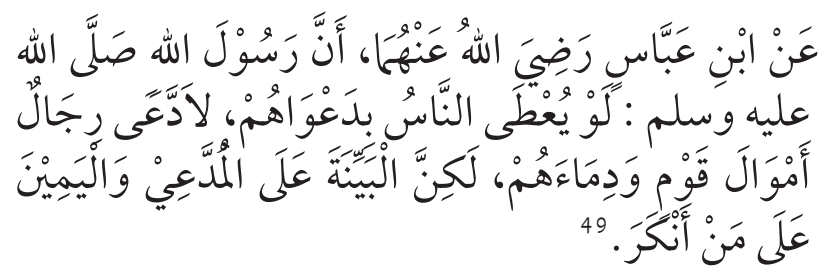

Terjemahan: "Dari Ibn 'Abbās RA, sesungguhnya Rasulullah SAW bersabda: "Sekiranya setiap tuntutan orang diterima begitu saja, nescaya orang-orang

48 Dr. Drs. Amran Suadi, SH, M.Hum, M.M.(Hakim Agung Mahkamah Agung R.I), dalam temu bual bersama penulis pada 7 Mac 2017; Drs. Muhajir, SH, M. Hum (Hakim Agama Mahkamah Agama, Bojonegoro), dalam temu bual bersama penulis pada 25 Januari 2017.

49 Diriwayatkan oleh Imam al-Bayḥaqī dan sebahagian daripadanya diriwayatkan oleh Bukhari dan Muslim. Al-Nawawī, Abū Zakariyyā Mahyy al-Dīn Ibn Sharf, Arba 'ìn al-Nawawiyah (Riyāḍ: al-Maktab al-Ta'āwun li al-Da'wah wa al-Tauiyah al-Jaliyat, 2007), 70. 
akan menuntut darah orang lain atau hartanya. Tetapi haruslah ada bukti atau saksi bagi yang menuntut dan bersumpah bagi yang menafikan (dakwaan)".

Dalam kes ini antara plaintif dengan defendan mengaku bahawa mereka merupakan satu-satunya anak dari pewaris dengan sama-sama mengemukakan saksi dan alat bukti berupa buku nikah dengan tarikh dan tempat sama, sehingga akhirnya hakim menerima permohonan plaintif untuk menyatakan sumpahnya sebagai penguat bukti atau bukti tambahan dari dakwaannya. Dengan menggunakan metode ini, keputusan hakim dapat diperkatakan bersesuaian dengan syarak kerana memenangkan individu yang dapat mendatangkan bukti yang banyak berupa $a l$ firasy, kesaksian dan perakuan.

Seterusnya berkaitan dengan membatalkan semula hibah yang diberikan kepada defendan dan turut defendan I dan turut defendan II, Hakim Agung Amran Suadi dan Hakim Muhajir mengatakan bahawa majlis hakim dalam kes ini menggunakan metode argumentum a contario terhadap pasal $210 \mathrm{KHI}$ yang memperuntukkan: "orang yang telah berumur sekurang kurangnya 21 tahun, berakal sehat dan tanpa paksaan dapat menghibahkan sebanyak banyak 1/3 harta bendanya kepada orang lain atau institusi di hadapan dua orang saksi untuk dimiliki". Dalam kes ini hakim memutuskan sesuatu yang berbeza dengan apa yang termaktub di dalam pasal tersebut sehingga berlaku hukum sebaliknya. ${ }^{50}$

Pengkaji melihat hakim menggunakan metode ini terhadap KHI pasal 210 kerana sesuai dengan tuntutan plaintif bahawa tanah yang telah dihibahkan kepada defendan dan turut defendan I dan defendan II dilakukan secara paksa oleh mereka, dan hibah tersebut berlaku dalam keadaan pewaris sedang sakit. Namun menurut pengkaji hibah tersebut berlaku kerana hubungan keakraban antara pewaris dengan orang yang menerima hibah, kerana pewaris memberi hibah kepada cucu yang tinggal

50 Dr. Drs. Amran Suadi, SH, M.Hum, M.M.(Hakim Agung Mahkamah Agung R.I), dalam temu bual bersama penulis pada 7 Mac 2017; Drs. Muhajir, SH, M. Hum (Hakim Agama Mahkamah Agama, Bojonegoro), dalam temu bual bersama penulis pada 25 Januari 2017. 
bersamanya yang merupakan anak daripada Ismunandar itu sendiri (plaintif) dan hibah tersebut berlaku antara tempoh masa yang lama dengan meninggalnya pewaris.

Tambahan pula menurut Hakim Agung Amran Suadi yang menyatakan bahawa majlis hakim juga menggunakan metode tafsiran ekstensif. Iaitu hakim dalam menafsirkan undangundang yang melebihi batasan-batasan kebahasaan terhadap KHI pasal 209 ayat 2. ${ }^{51}$ Di dalam KHI pasal 209, wasiat wajibah hanya diberikan kepada ibu bapa angkat atau anak angkat sahaja, namun pada kenyataannya hakim juga memberikan bahagian waris kepada defendan, turut defendan I dan II melalui perangkat wasiat wajibah padahal mereka bukanlah anak angkat dari pewaris, malahan defendan adalah anak yang dipertikaikan kesahan nasabnya kepada pewaris. Sementara turut defendan I dan II merupakan cucu kandung daripada pewaris atau anak dari plaintif. Hakim memperluas makna anak angkat kepada cucu pewaris dan juga yang mengaku anak dari pewaris itu sendiri (hakim telah menerima sumpah plaintif yang menyatakan bahawa plaintif merupakan satu-satunya anak dari pewaris dan hakim membatalkan perakuan dari defendan sebagai anak pewaris).

Namun dalam pandangan pengkaji, tidak sepatutnya cucu diberikan wasiat wajibah, apatah lagi ibu bapa kandung daripada cucu tersebut juga masih hidup. Maka harta pusaka tetap diberikan secara mutlak kepada ahli waris pewaris itu sendiri. Namun kerana cucu tersebut telah merawat pewaris, maka hibah yang telah diberikan pewaris kepada cucu adalah wajar dan tidak perlu ditarik semula. Demikian juga hibah yang telah diberikan oleh pewaris kepada defendan meskipun hakim membatalkan ianya sebagai anak dari pewaris, maka sepatutnya hibah yang telah diberikan kepadanya juga tidak dicabut semula kerana bukan hibah kepada anak. Sekiranya ianya digolongkan kepada anak, maka hakim harus berbuat adil yang sama terhadap plaintif. Pengkaji melihat bahawa pengalihan harta kepada bukan ahli waris melalui instrumen hibah adalah sesuatu yang selari dengan Islam berdasarkan sabda Rasulullah SAW sepertimana berikut:

51 Dr. Drs. Amran Suadi, SH, M.Hum, M.M.(Hakim Agung Mahkamah Agung R.I), dalam temu bual bersama penulis pada 7 Mac 2017. 


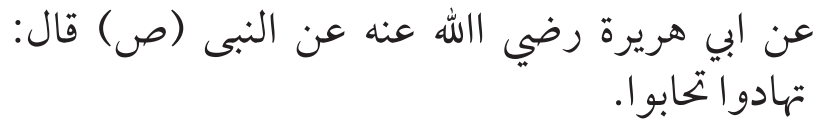

Terjemahan: "Dari Abī Hurayrah RA dari Nabi SAW bersabda: "Saling memberi hadiahlah nescaya akan saling mencintai". ${ }^{52}$

Jika alasan hakim membatalkan hibah dengan sebab ia tidak tercatat, maka dalam sorotan fiqh, tidak ada keterangan tentang ketentuan bahawa dalam akad hibah terdapat suatu syarat agar dalam pelaksanaan hibah harus disiapkan alat-alat bukti, saksi atau surat-surat kuat yang menjadi syarat sahnya hibah. Apatah lagi anak pewaris (plaintif) juga membenarkan adanya hibah yang diberikan kepada defendan dan turut defendan I serta turut defendan II. Meskipun demikian, pengkaji tidak menafikan dalam al-Quran menganjurkan dalam aspek muamalah yang dilakukan secara tunai seperti pelaksanaan perjanjian kesopanan sivil yang termasuk hibah, sebaiknya terdapat alat bukti, sebab dengan adanya alat bukti itu akan menimbulkan kemantapan bagi yang menghibahkan mahupun bagi yang menerima hibah. Jika di kemudian hari berlaku sesuatu hal dengan hibah yang diberikan, maka dengan adanya alat-alat bukti, perkara tersebut akan mudah diselesaikan. Walau bagaimanapun, ketiadaan bukti tertulis tidak boleh dijadikan alasan untuk menarik hibah dan menggantikannya dengan wasiat wajibah.

Oleh yang demikian, peralihan harta melalui hibah diiktiraf oleh syarak, sementara peralihan harta melalui wasiat wajibah masih menjadi perbahasan, lebih-lebih lagi kepada cucu yang terhalang oleh bapanya sendiri, dan kepada orang lain (yang sudah dibatalkan oleh hakim sebagai anak).

Manakala hakim Zamroni menambahkan bahawa majlis hakim dalam kes ini juga menggunakan metode tafsiran sistematik. Melalui metode ini, hakim membandingkan aturan yang termaktub dalam KHI dengan Undang-Undang No. 5 tahun 1960 tentang agraria dalam rangka menolak sijil yang dimiliki oleh defendan bukanlah bukti yang kuat disebabkan sistem publikasi negatif yang

52 Hadis riwayat al-Bukhari. Lihat Muhammad Sa‘̄̄d Ruslan, Sharmmad Sa 'ìd Ruslan, (Qāhirah: Dār al-Ḥadīth, 2010), 82. 
memberikan kesempatan orang lain untuk membatalkan kesahan sijil tersebut. ${ }^{53}$ Menurut pengkaji, pada hakikatnya penggunaan metode ini bukan merupakan sesuatu yang bertentangan menurut perspektif syarak terlebih dalam rangka sad dzariah. Namun berkaitan dengan kes ini sepatutnya hakim menjunjung konsep hibah secara utuh, tidak menutup kemungkinan hibah yang diberikan pewaris kepada cucu dan anak yang sudah dibatalkan oleh hakim sebagai anaknya merupakan amal jariah pewaris.

\section{KESIMPULAN}

Hakim memberikan wasiat wajibah kepada anak tak sah taraf dan mencabut semula semua hibah yang telah diberikan kepadanya disebabkan terdapat anak sah yang mewarisi harta yang meninggal dunia. Metode yang diguna pakai oleh hakim adalah metode tafsiran ekstensif dengan memperluaskan pemberian wasiat wajibah yang dalam KHI hanya diberikan kepada anak angkat, tetapi hakim memperluaskan dengan memberikannya kepada anak tak sah taraf. Sementara keputusan mencabut semula hibah hakim menggunakan metode argumentum a contrario di mana pewaris dianggap terpaksa dalam memberikan hibah. Dalam perspektif syarak, keputusan dan metode penghakiman tersebut tidak sesuai dengan syarak kerana mencabut pemberian hibah yang hakikatnya sudah selari dengan syarak tetapi digantikan dengan memberikan wasiat wajibah yang hukumnya masih dipertentangkan.

\section{RUJUKAN}

Abū al-Wālid Muḥammad Ibn Aḥmad Ibn Muḥammad Ibn Aḥmad Ibn Rushd, Bidāyah al-Mujtahid wa al-Nihāyah alMuqtașid, vol. 3 (Bayrūt: Dār al-Ma'rifah, 1978).

Bandar bin Fahd as-Suwailim, al-Bashmah al-Waratsiyah wa Atsaruha fin Nasab (Yordania: Dār al-Nafâis, 2006).

Chatib Rasyid, "Menempatkan anak yang lahir di luar nikah secara hukum Islam", Muzakarah Majelis Ulama Indonesia (MUI) (Medan: MUI, 2005).

53 Drs. Zamroni, SH. M. Hum. (Hakim Agama Mahkamah Agama Sumenep) dalam temu bual bersama penulis pada 23 Januari 2017. 
Chua Yan Piaw, Kaedah dan Statistik Pengkajian: Asas Statistik Pengkajian Buku 2 (Malaysia: McGraw-Hill, 2006).

Fauzan, Kaidah Penemuan Hukum Yurisprudensi Bidang Hukum Perdata (Jakarta: Kencana, 2014).

Ḥasanayn Muḥammad Maklūf, al-Mawārith fì al-Sharī'ah alIslāmiyyah (t.t.p.: Maṭba'ah al-Madan̄̄, 1996).

Hilman Hadikusuma, Hukum Waris Adat (Bandung: PT. Citra Aditya Bakti, 1999).

Ibn Ḥazm al-Andalūsī, al-Muhallā bi al-Athar, vol. 9 (Bayrūt: Dār al-Kutub al-'Ilmiyyah, 2003).

Ibn Taymiyyah, Abū al-'Abbās Taqī al-Dīn Aḥmad Ibn 'Abd alHalīm, Majmū' al-Fatawā li Ibn Taymiyyah, vol. 20 (t.t.p.: al-Maktabah at-Tawfĩqiyah, t.t.).

Khalifah 'Al̄i Al-Ka'bi, Al-Bashmah Al-Wiratsiyah (Yordania: Dār Al-Nafâis, 2006).

M. Thahir Maloko, "Anak sah dan anak luar nikah," Ar-Risalah 10, no. 1 (2010), 43-50.

Moh Muhibbin," Wasiat Wajibah untuk Anak Angkat, Anak di Luar Perkahwinan Yang Sah dan Anak dari Ibu bapa Beda Agama," dalam Problematika Hukum Kewarisan Islam Kontemporer di Indonesia, ed. Muchit A. Karim (Jakarta: Kementrian Agama RI Badan Litbang dan Diklat Puslitbang Kehidupan Keagamaan, 2012).

Muhammad Sa‘̄id Ruslan, Sharh al-Ādab al-Mufrad (Qāhirah: Dār al-Hadīth, 2010).

Al-Nawawī, Abū Zakariyyā Mahy al-Dīn Ibn Sharf, Arba ìn alNawawiyah (Riyāḍ: al-Maktab al-Ta‘āwun li al-Da'wah wa al-Tauiyah al-Jaliyat, 2007).

Paizah Ismail, "Anak tak sah taraf dari perspektif syariah dan perundangan Islam di Malaysia", Jurnal Fiqh, no. 10 (2013), 77-90.

Al-Șan'ānī, Muḥammad Ibn Ismā'îl al-Kahlanī Abū Ibrāhim, 'Izz al-Dīn, Subl al-Salām Sharḥ Bulūgh al-Maram, vol. 1 (Semarang: Maktabah Toha Putera, t.t.).

Sayyid Sābiq, Fiqh al-Sunnah, vol. 3 (Bayrūt: Dār al-Kutub 'Arabī, 1989). 
Al-Shawkān̄i, Muḥammad Ibn 'Alī Ibn Muḥammad, Nayl alAwțār fì Sharh Muntaqā al-Akhbār, vol. 6 (Bayrūt: Dār alKutub 'Arabī, 2002).

Sudikno Mertokusumo dan A. Plito, Bab-Bab tentang Penemuan Hukum, Cet.2 (Bandung: Citra Aditya Bakti, 2013).

Suparman Usman \& Yusuf Somawinata, Fiqh Mawaris: Hukum kewarisan Islam (Jakarta: Gaya Media, 1997).

Wahbah al-Zuhaylī, al-Fiqh al-Islāmī wa Adillatuhu, vol. 3 (Damshiq, Syria: Dar al-Fikr, 1989).

Zakiul Fuady M. Daud, Belajar Praktis Fiqih Mawaris (Takengon, Shakura, 2018).

Zakiul Fuady Muhammad Daud \& Raihanah Azahari, "Amalan penghakiman dalam kes Wasiat wajibah kepada waris berbeza agama: Kajian kes terpilih," Jurnal Syariah 26, no 2 (2018), 267-294.

Zakiul Fuady Muhammad Daud \& Raihanah Azahari, "The wajibah will: Alternative wealth transition for individuals who are prevented from attaining their inheritance," International Journal of Ethics and Systems 10.1108/ IJOES-09-2018-0133.

Zakiul Fuady Muhammad Daud \& Raihanah Azahari, "Wasiat wajibah kepada anak angkat: Analisis terhadap keputusan dan metode penghakiman dalam kes No 459/Pdt.G/2013/ PTA Sby,” Jurnal Fiqh, no 15 (2018), 41-60.

\section{Statut}

Undang-Undang RI No. 1 Tahun 1974.

\section{Fatwa}

Fatwa Majelis Ulama Indonesia Nombor 11 tahun 2012 tentang Kedudukan Anak Hasil Zina dan Perlakuan Terhadapnya (Jakarta: Komisi Fatwa Majelis Ulama Indonesia).

Rabithah al-'Alam al-Islami, Fatwa al-Majma' al-Fiqhi al-Islami pada muktamar ke-16 (Mekkah, 2002). 


\section{Temu bual}

Dr. Drs. Amran Suadi, SH, M.Hum, M.M. (Hakim Agung, Mahkamah Agung R.I), dalam temu bual bersama penulis pada 7 Mac 2017.

Drs. Muhajir, SH, M. Hum (Hakim Agama, Mahkamah Agama, Bojonegoro), dalam temu bual bersama penulis pada 25 Januari 2017.

Drs. Zamroni, SH. M. Hum (Hakim Agama, Mahkamah Agama Sumenep) dalam temu bual dengan penulis pada 23 Januari 2017. 